\title{
Revenue Generation Aspects That Influence Financial Sustainability of Public Water Utilities in Kenya: The Case of Homa Bay Water and Sewerage Company Limited
}

\author{
Agwa Maryline Akinyi $^{1} \&$ Paul A. Odundo ${ }^{2}$ \\ ${ }^{1}$ Department of Extra-Mural Studies, University of Nairobi, Nairobi, Kenya \\ ${ }^{2}$ Department of Education Communication \& Technology, University of Nairobi, Nairobi, Kenya \\ Correspondence: Paul A. Odundo, Associate Professor, Department of Education Communication \& Technology, \\ University of Nairobi, Nairobi, Kenya.
}

Received: October 30, 2017

doi:10.20849/abr.v3i2.370
Accepted: March 28, 2018

Online Published: April 23, 2018

URL: https://doi.org/10.20849/abr.v3i2.370

\begin{abstract}
Water sector reforms entrenched commercialization of water services and necessitated establishment of autonomous public utilities to cushion poor citizens from high market prices and guarantee access to water. The purpose of this study was to demonstrate how well the utility prepared its revenue generation operations to achieve financial sustainability in the commercialized water market. A cross-sectional design, with mixed methods approach, was applied, and primary data sourced in mid-2017 from water officers, users and committee members. Quantitative analysis techniques included cross-tabulation with Chi square statistic, Relative Importance Index and Kendall's Coefficient of Concordance. The results show that non-revenue water was the most important aspect of revenue generation influencing the utility's financial sustainability (relative weight $=$ 0.879 ); followed by efficiency of the billing system (relative weight $=0.866$ ); efficiency of revenue collection (relative weight $=0.853$ ); and unaccounted for water (relative weight $=0.790)$. A strong and significant concordance of views expressed by different respondents implied that the revenue generation pillar was not adequately set to enable the utility achieve financial sustainability in the commercialized water market (Kendall's $\mathrm{W}=0.893, \chi^{2}=71.222, \mathrm{df}=4 \& \rho$-value $=0.000$ ). The study amplifies need for the utility to control non-revenue and unaccounted for water; forge active partnership with community administrative structures and groups for early detection and reporting of physical leakages, pilferage and defective metering equipment; among other measures.
\end{abstract}

Keywords: public water utility, revenue generation, financial sustainability, reforms, commercialization

\section{Introduction}

Access to safe drinking water and appropriate sanitation is a universal stimulus for socio-economic and human development, particularly by improving maternal and child health, girl-child education, economic productivity and environmental sustainability (Poverty-Environment Partnership [PEP], 2006; United Nations Development Programme [UNDP], 2010). Traditionally, provision of water services has been a function of governments through their agencies, including ministries, departments, state corporations and local government authorities, particularly because water is a service of public interest and a basic element of human rights (Gia \& Fugelsnes, 2010; UNDP, 2010; K'Akumu, 2006; PEP, 2006).

In many developing countries, delivery of water services by governments has been characterized by challenges such as inefficient billing systems, ineffective revenue collection practices, low revenues, large proportions of non-revenue and unaccounted for water, high default rates, low cost recovery, poor financial management practices, as well as unaccountable management systems (Gia \& Fugelsnes, 2010; Whittington, Davis, Prokopy, Komives, Thorsten, Lukacs \& Wakeman, 2009; K'Akumu, 2006). The challenges stimulated pro-reform movements in the water sector, which began in the mid-1980s for most Sub-Sahara African (SSA) countries; and gathered momentum in the 1990s, following the development of necessary legal and policy frameworks (Banerjee \& Morella, 2011).

The early phases of water reforms in the SSA were agitated for and driven by international development agencies led by the World Bank. The agitators demanded more efficient and sustainable water management approaches, 
which would involve increasing private sector participation, reducing the role of government in direct delivery of water services and improving internal governance (Banerjee \& Morella, 2011; World Bank, 2008; K'Akumu, 2006). In Kenya, pro-reform movements in the water sector began in late 1980s, with the introduction of World Banks' Structural Adjustment Programs, which required the government to delegate responsibility for operations, maintenance, financial management and service delivery to the private sector. The pro-reform momentum culminated to the first National Policy on Water Resources Management and Development, which was formulated in 1999 (Water Resources Management Authority [WRMA], 2013; Rampa, 2011; World Bank, 2008; K'Akumu, 2006).

The National Water Policy called for decentralization of operations from the central government to other actors, including local authorities and the private sector; increased involvement of communities to improve efficiency and sustainability in service delivery; as well as amendment of the then Water Act Cap 372 to enhance its relevance in supporting sector reforms, among other features (Obosi, 2011). This led to enactment of the Water Act 2002, which provided a crucial legal foundation for water sector reforms, encompassing management of water resources, elimination of government's participation in direct delivery of services, provision of a mechanism for financing water initiatives as well as strengthening the institutional framework (Obosi, 2011; Rampa, 2011; World Bank, 2008). Figure 1 shows the institutional framework created by the Water Act 2002, to enhance protection and management of water resources, as well as delivery of water and sanitation services.

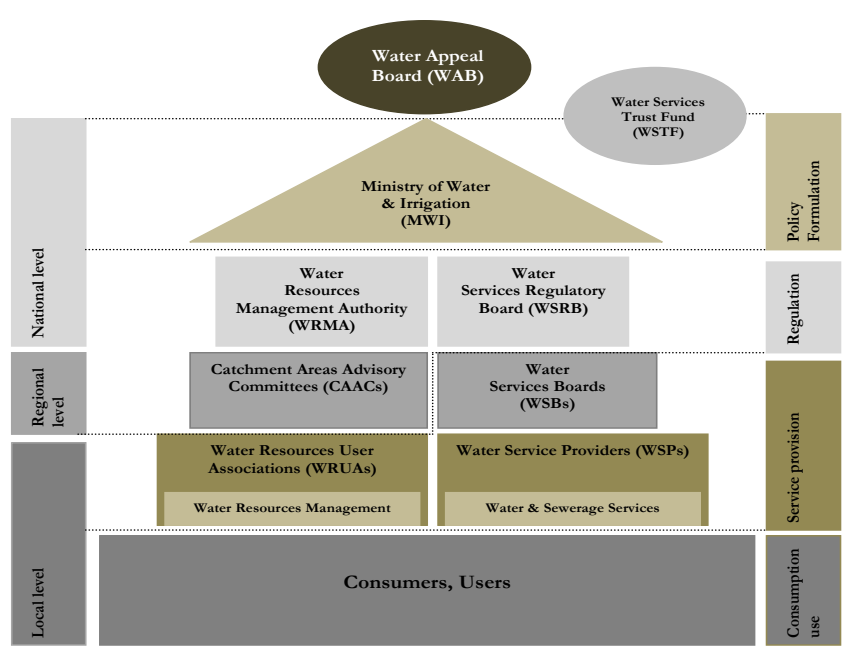

Figure 1. The institutional framework created by the Water Act 2002

Source: Rampa, 2011

At the regional level, the Act created eight Water Services Boards (WSBs), including Lake Victoria South Water Services Board (LVSWSB), whose jurisdiction covers eight counties, including Homa Bay. The Gazette Notice No. 1714 of March 2004 specifies functions of WSBs to include asset development and ownership; contracting and managing Water Service Providers (WSPs); as well as ensuring efficient and economical provision of water and sanitation services, among others (K'Akumu, 2006). WSPs are agents authorized by WSBs through Service Provision Agreements (SPAs) to provide water and sanitation services, as well as develop, rehabilitate and maintain facilities on behalf of WSBs. According to the Act, WSPs include public and private companies, non-governmental organizations, individuals and community-based organizations contracted by a WSB to provide water and sanitation services in a particular geographical area, in accordance with terms specified in binding SPAs (Obosi, 2011; Norman \& Parker, 2011; Rampa, 2011; World Bank, 2008; Government of Kenya, 2002).

By opening up the water market to players from all sectors and introducing business principles and management practices in the sector, the reforms entrenched the aspect of commercialization in water and sanitation service delivery with the aim of improving cost recovery, efficiency and sustainability (K'Akumu, 2006). However, commercialization of the water market meant that all citizens were exposed to a scenario where access to water services and the cost of water would be determined by the forces of demand and supply. Recognizing that commercialization of the water market would disadvantage poor citizens, the Water Act 2002 permits the 
government to deliver services indirectly through autonomous public limited companies, in which the government would hold shares and power to regulate tariffs to cushion poor citizens from high market prices and guarantee access to water as a basic human right. This prompted the creation of autonomous public limited companies, hereafter referred to as public water utilities. One such public water utility was the then South Nyanza Water and Sewerage Company (SNWSC), which was incorporated in 2007 to provide water and sewerage services in the then, Rachuonyo, Homa Bay and Suba Districts. When the governance system was devolved to counties in 2013, SNWSC was taken over by the County Government of Homa Bay and rebranded as Homa Bay Water and Sewerage Company Limited (HOMAWASCO), hereafter referred to as 'the utility' (WRMA, 2013; Norman \& Parker, 2011; Rampa, 2011; K'Akumu, 2006).

Delivery of competitive water and sanitation services in a commercialized water market requires public water utilities to orient their operations towards efficiency, cost recovery and financial sustainability. Financial sustainability enables organizations to maintain general operations, ensure continuous delivery of services and invest in infrastructural expansion. Besides, organizations that are financially sustainable have better chances of seizing opportunities and reacting to unexpected challenges without depending on external funding sources (Williams, 2013; McPhail, Locussol \& Perry, 2012; Bowman, 2011). In the water sector context, a public water utility is considered to be financially sustainable when it's able to generate sufficient revenues to off-set its Operational and Maintenance (O\&M) costs as well as finance the development of infrastructural facilities. Internally generated revenue is particularly important because it enables public water utilities to lessen the intensity of shocks caused by sudden changes in funding from external sources (Williams, 2013; McPhail et al., 2012; Sanders \& Fitts, 2011).

Studies conducted in various countries across the globe, provide anecdotal evidences, which suggest that water utilities have achieved varying levels of success in revenue generation and financial sustainability. For instance, in a multi-country study that covered Bolivia, Peru and Ghana, Whittington et al. (2009) reported that rural water utilities substantially improved billing accuracy, revenue collection efficiency, and reduced unaccounted for water, which in turn, enabled the utilities to eliminate water rationing. Similar findings appear in the outputs of studies conducted by Check (2015); Abebe, Bosona and Gebresenbet (2013); Adank and Tuffuor (2013), Mimrose and Gunawardena (2011), Fragano (2010) and World Bank (2006), among others. Details are highlighted under the literature review section.

In Kenya, a few studies conducted over the past decade have reported mixed results of successes and failures regarding water sector reforms, revenue generation and financial sustainability of public water utilities. For instance, in 2012, World Bank commissioned a study, which associated the reforms with achievements such as higher and reliable stream of revenue, which enabled public water utilities expand and maintain distribution systems; thereby, reduce water rationing and loss through leakages, spillage and pilferage (World Bank, 2012). Even though the study highlighted overall outcomes of the reforms, it did not delve into the relationship between revenue generation aspects and financial sustainability of public water utilities. Moving on, periodical water sector review reports published by water authorities associate water sector reforms with improved revenue collection efficiency, a reliable stream of finances, as well as a reduction in the amount of water lost through burst pipes, leakages and pilferage. The reports also identify issues that still dim achievements in revenue generation and financial sustainability, including low coverage of rural communities, poor corporate governance practices, diversion of water revenues, among other challenges (UNICEF \& WHO, 2015; WASRB, 2013; World Bank, 2012).

In his study, which focused on privatization of water in Kenya, Wambua (2004) examined three public water utilities, namely, Nairobi Water and Sewerage Company Limited (NAWASCO), Nyeri Water and Sewerage Company Limited (NYEWASCO) and Eldoret Water and Sewerage Company Limited (ELDOWAS); to demonstrate early successes and failures of water sector reforms. As the best performer, NYEWASCO reported improved revenue collection, the bulk of which was ploughed back to improve service delivery; prompt repair of burst pipes, which reduced water loss; as well as increased proportion of metered connections, which translated to a higher revenue base. As the worst performer, NAWASCO reported attributes such as loss of up to $50 \%$ of pumped water, low proportion of metered consumers, ad hoc meter readings, poor revenue collection of less than 60\%; as well as bloated workforce, which consumed much of water revenues (Wambua, 2004). Notably though, Wambua's study did not focus on statistical relationship between revenue generation aspects and financial sustainability of utilities.

This study differs from its predecessors in terms of geographical setting, as well as methodological and analytical approaches. Its purpose was determine revenue generation aspects that influence the utility's financial sustainability, with a view to demonstrating how well the utility prepared its revenue generation 
operations in order to achieve financial sustainability in a commercialized water market. The output of the study was expected to contribute to policy discourses and management of public water utilities; as well as stimulate relevant research to aid sector development, not only in Kenya but also in other developing countries.

\section{Literature Review}

A key feature of water sector reforms in Kenya is the commercialization of water services, which entailed subjecting such services to market forces and operating public water utilities on business principles to achieve efficiency, cost-recovery and financial sustainability (Obosi, 2011; World Bank, 2008; K'Akumu \& Appida, 2006; Wambua, 2004). According to Sanders and Fitts (2011), financial sustainability implies the ability of water utilities to defray O\&M costs consistently, and to maintain an acceptable level of services over time; while Adams (2012) observes that a water utility is financially sustainable if the management is able to recover full costs for O\&M, as well as retain sufficient revenues for capital investments. Whereas operational costs arise from daily management of water utilities, including pump operation, water treatment, rationing, network surveying, recording and reporting; maintenance costs include costs emanating from technical aspects such as availability of spare parts and technical skills, replacement of worn-out parts, as well as administrative and managerial actions that keep water supply systems running (Castro, Msuya \& Makoye, 2009).

Maintenance costs vary significantly, depending on the type of maintenance activity under consideration. In this regard, Castro et al. (2009) identifies preventive, corrective and rehabilitative types of maintenance. Whereas preventive maintenance is planned and executed regularly to keep water infrastructure in good working condition; corrective maintenance involves activities responding to breakdowns or infrastructure deterioration, while rehabilitative maintenance involves repair of major defects to restore water supply. Financial sustainability of public water utilities is indicated by aspects such as the consistency of preventive maintenance, duration between occurrence of breakdowns and onset of corrective maintenance, as well as interludes between any two successive rehabilitative sessions (McPhail et al., 2012; Castro et al., 2009).

All organizations, whether public or private, profit or non-profit, strive to achieve financial sustainability in order to deliver services consistently; thereby, ease pressure and dependency on external sources, which include multilateral loans and/or grants; public budgetary allocations and equity investments, among others (Williams, 2013; McPhail et al., 2012; Bowman, 2011). Over the past two decades, development practitioners and scholars have come up with various theoretical models to deepen and widen understanding of organizational financial sustainability in various sectors and contexts. One such initiative culminated to the Four Pillars Model of Financial Sustainability, which was developed in 2001 by Nature Conservancy, in collaboration with the United States Agency for International Development. The model's purpose was to enable all development organizations strengthen their capacity to achieve financial sustainability and deliver lasting services without depending on external funding sources (McPhail et al., 2012; Bowman, 2011; Leon, 2001).

The Model posits that organizational financial sustainability anchors on four fundamental pillars, including strategic and financial planning, income diversification, sound administration and financial management, as well as own income generation (McPhail et al., 2012; Leon, 2001). Own income generation pillar is the principal avenue through which organizations can surmount financial constraints and achieve financial sustainability (McPhail et al., 2012). Own income enables organizations to cushion against shocks that may arise from sudden changes in funding from external sources. One advantage that comes with own income is that organizations have unrestricted authority on its utilization. Organizations can generate own income through multiple ways, and the ones adopted depend on its mission and purpose in society. Whatever ways adopted, organizations must strive to enhance efficiency and optimize opportunities in order to achieve financial sustainability (McPhail et al., 2012). The four pillars model provided the theoretical basis for the study.

In the Kenyan water sector, commercialization of services requires public water utilities to improve revenue generation operations, as an indispensable prerequisite for financial sustainability (World Bank, 2008; K'Akumu \& Appida, 2006). In this regard, water utilities are expected to improve billing and revenue collection efficiency, optimize water tariff, as well as reduce non-revenue water and unaccounted for water. Non-revenue water is the difference between the volume of water put into the distribution system and the volume that is billed for authorized consumption, caused by water losses due to leakages, spillage from storage tanks, illegal connections and inaccurate metering. Non-revenue water also includes authorized, but unbilled consumption such as through community stand posts and firefighting. On the other hand, unaccounted for water is the difference between the volume of water delivered into a network and the volume of water that can be accounted for by legitimate consumption, due to leakage or theft (Frauendorfer \& Liemberger, 2010; World Bank, 2006). 
The relationship between revenue generation aspects and financial sustainability of water utilities is a subject that has not received adequate attention in previous studies. Only a few such studies, which were conducted in various developing countries, provide anecdotal evidences regarding linkage between the two concepts. For instance, Check (2015) reported a significant correlation between financial sustainability of private water schemes in Uganda and community purchasing power, which was measured in terms of household annual income. In this regard, a water scheme located in communities with regular income was about thrice as likely to recover O\&M costs as that located in communities with seasonal income. Besides, water schemes in communities with regular income were found to be more reliable in providing services than those in communities with seasonal income; which suggests that community purchasing power is likely to influence financial sustainability of water utilities.

In Ethiopia, Abebe, Bosona and Gebresenbet (2013) reported that about 55\% of respondents were dissatisfied with the quality of services provided by public water schemes due to rationing, which dissuaded community members from paying for services. The authors argued that dissatisfaction with the quality of services reduced level of demand, which in turn, affected the amount of revenue generated and the ability of the schemes to achieve financial sustainability. In their study, Adank and Tuffuor (2013) reported a significant association between financial stability of private water schemes in Ghana and factors such as non-revenue water, metering coverage and efficiency of general operations. More still, Sanders and Fitts (2011) found a significant relationship between cost recovery of water supply schemes in Tanzania and the amount of tariffs charged per unit of water consumed. In conclusion, the authors amplified the importance of balancing water tariffs with parameters such as O\&M costs as well as community purchasing power.

In Sri Lanka, Mimrose and Gunawardena (2011) also reported some linkage between financial stability of public water schemes and revenue generation aspects such as efficiency of billing systems, efficiency of revenue collection, non-revenue water as well as unaccounted for water. In Paraguay, Fragano (2010) reported that 67\% of water projects involved in the study were consistent in providing services due to financial stability, $54 \%$ were in a good state of maintenance, while $29 \%$ had either expanded or were in the process of expanding their infrastructural systems. The achievements were attributed to near-universal metering, computerized billing systems, a high level of revenue generation, as well as favorable water tariff coupled with reliable services, which stimulated consumers to pay. In a multi-county study, World Bank (2006) also reported a significant correlation between financial viability of rural water schemes in developing countries and two aspects of revenue generation, including non-revenue water and unaccounted for water.

In Kenya, Kibuika and Wanyoike (2012) revealed a strong negative correlation between financial sustainability of rural water schemes and the amount of unaccounted for water $(r=-0.656 ; \mathrm{p}<0.01)$. The authors attributed the large amount of unaccounted for water to multiple factors, including delayed maintenance of distribution lines, low operational efficiency, theft, inaccurate billing system, bad meters and low revenue generation. Still in Kenya, Norman and Parker (2011) found that introduction of mobile phone payment method, helped residents of Kiamumbi community in the outskirts of Nairobi to pay their bills without going to queue in banks, which in turn, improved revenue generation and cost recovery for their water utilities. Notably though, little is documented regarding revenue generation aspects that influence HOMAWASCO's financial sustainability.

The study applied the conceptual framework indicated in Figure 2, which was conceived from the Four Pillars of Financial Sustainability Model. The framework shows the hypothesized relationship between each pillar (concept) and the utility's financial sustainability. Each pillar was operationalized in terms of measurable aspects, which were designated as independent variables.

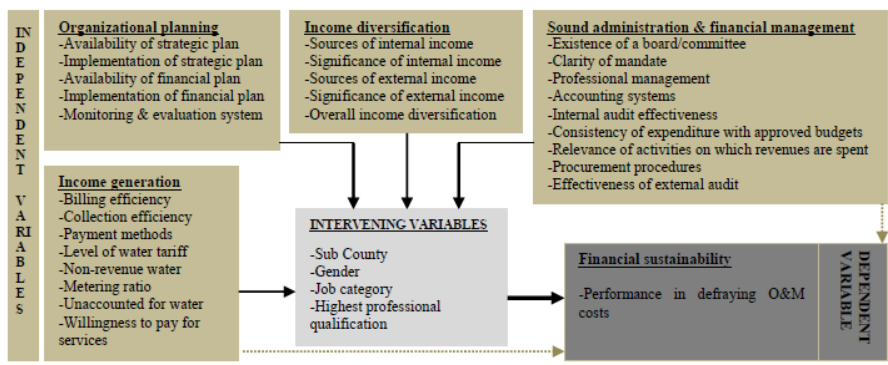

Figure 2. Conceptual framework showing hypothesized relationship between key concepts 
This article focuses on the relationship between the income/revenue generation pillar and the utility's financial sustainability. In this regard, the pillar was operationalized in terms of efficiency of the billing system, efficiency of revenue collection, appropriateness of water tariff in relation to cost recovery, non-revenue water, as well as unaccounted for water; while financial sustainability was measured as the utility's performance in defraying O\&M costs over the preceding one year period.

\section{Methodology}

The study design was informed by two philosophical approaches of social science research, including positivism and constructivism. The positivist school of thought holds that information derived objectively from sensory experience with phenomena is the exclusive source of all authoritative knowledge, provided that the phenomenon in question and the researcher are mutually independent. Positivist scholars focus on determining causal relationships between sets of phenomena by testing null hypotheses. On the other hand, the constructivist school of thought believe that phenomena are socially constructed and are subjectively observed, which implies that constructivist researchers are part of the phenomenon being observed. A constructivist researcher focuses on the meaning of phenomena observed, examines its totality and induces generalizations (Wong, 2014; Ashley \& Orenstein, 2005; Easterby-Smith, Thorpe \& Lowe, 1991).

The study was designed to capture cross-sectional data to enable the investigators determine bivariate and causal relationships between revenue generation aspects and the utility's financial sustainability, in accordance with the tenets of positivism. The study was also designed to source qualitative data using Key Informant Interviews (KIIs) and Focused Group Discussions (FGDs), in accordance with the constructivist school of thought. The information was used to examine the totality of relationship between revenue generation aspects and the utility's financial sustainability. Based on the positivist and constructivist thoughts, the investigator applied a mixed methods approach; where quantitative methods elicited information for descriptive and inferential purposes, while qualitative methods obtained detailed case analysis information for validating quantitative results (Sale, Lohfeld \& Brazil, 2002; Hughes \& Sharrock, 1997).

The study targeted six rural water schemes, managed by HOMAWASCO. Within the schemes, the study targeted water officers, who were grouped into five job categories, including managerial, operations, technical, commercial and finance. The study also targeted three groups of water users, including commercial, government and domestic. Commercial users included restaurants and guest houses, fish processors, launders, and car washers. Government institutions included health facilities, ministries and academic institutions; while domestic users include household heads. In addition, the study targeted scheme management committee members. The quantitative approach targeted water officers in five job categories, whose distribution is indicated in Table 1.

Table 1. Distribution of the populations and sample sizes for various categories of water officers

\begin{tabular}{lllll}
\hline Job category & Specific cadre & Population $\left(\mathbf{N}_{\mathbf{i}}\right)$ & Sample $\left(\mathbf{n}_{\mathbf{i}}\right)$ & Sampling method \\
\hline \multirow{2}{*}{ Managerial } & CEO + Departmental heads & 5 & 5 & Census \\
& Scheme managers & 6 & 6 &, \\
Operations & Coordinators & 12 & 12 &, \\
& Station in-charges & 24 & 24 &, \\
Technical & Water engineers/technicians & 108 & 67 & Fisher's formula \\
& & & & \\
Commercial & Commercial officers & 150 & 86 &, \\
Finance & Finance officers & 10 & 10 & Census \\
Total & & $\mathbf{3 1 5}$ & $\mathbf{2 1 0}$ & \\
\hline
\end{tabular}

Fisher's formula for sample size determination from finite populations states that: $n_{i}=\left\{\frac{\delta(1-\delta)}{\left[\left(\frac{\alpha}{z}\right)^{2}+\delta(1-\delta) / N_{i}\right]}\right\} * \mu_{i}$

Where: $\mathrm{n}_{\mathrm{i}}=$ sample size, $\mathrm{N}_{\mathrm{i}}=$ population, $\delta=$ estimated population variance: $0.5, \alpha=$ desired precision: $0.05, \mathrm{Z}=$ confidence level: 1.96 for $95 \%$ on the normal distribution curve and $\mu_{\mathrm{i}}=$ design effect, default: 0.6 (Fink, 1995). Taking the example of commercial officers, whose population was 150 , the computation obtains a sample size of 
86 respondents. In addition, qualitative data were obtained through 12 KIIs and 6 FGDs.

Primary data were sourced between March and May 2017. A standard self-reporting survey questionnaire was applied to source quantitative data from water officers. The instrument was pre-tested in two water schemes in Siaya County, under the management of Siaya-Bondo Water and Sewerage Company Limited (SIBOWASCO). The pre-test covered 22 water officers, about $10 \%$ of the sample size, which according to Sheatsley (1983), is sufficient to discover flaws in data collection instruments. Content Validity Index (CVI) was computed for the survey questionnaire, and the process obtained a CVI of $64.7 \%$, which suggests that content validity was good, according to Polit and Beck (2006). Reliability of data collection questionnaire was determined by computing Spearman-Brown Prophecy Coefficient. The process obtained a Coefficient of 0.83, which according to Garson (2009), suggested a 'good' level of reliability.

Both quantitative and qualitative techniques were applied to process and analyze data. Quantitative techniques included cross-tabulation with Chi square statistic $\left(\chi^{2}\right)$ to determine the statistical association between revenue generation aspects and the utility's financial sustainability. Relative Importance Index (RII) was also applied to determine the relative importance of each aspect of revenue generation in relation to the utility's financial sustainability. Kendall's Coefficient of Concordance (W) was also applied to determine the extent to which respondents' views regarding the relative importance of revenue generation aspects vis-à-vis the utility's financial sustainability converged. All quantitative analyses were performed using the Statistical Package for Social Sciences (SPSS) and Microsoft Excel. In addition, qualitative data were transcribed and analyzed using Nvivo 10 to identify emerging themes and patterns.

Regarding ethical considerations, the investigators sought informed consent from respondents; and the process involved briefing them about the study, voluntary participation, withdrawal of consent and confidentiality of information sourced. Ethical clearance was obtained from the University of Nairobi Ethics and Research Committee; a research permit was obtained from the National Commission for Science, Technology, and Innovation, while introduction letters were obtained from the University of Nairobi and Ministry of Water Services and Environment, Homa Bay County.

\section{Results}

The results presented in the following sub-sections are organized under four thematic areas, including bivariate analysis of respondents' attributes and the utility's financial sustainability; as well as bivariate analysis of revenue generation aspects and the utility's financial sustainability. This is followed by relative importance analysis of revenue generation aspects, and concordance of respondents' views regarding the relative importance of revenue generation aspects vis-à-vis the utility's financial sustainability. The study required respondents to indicate their honest views regarding the utility's performance in defraying $O \& M$ costs on a four-point measurement scale, which was calibrated as 'very good', 'good', 'poor' and 'very poor'. The results show that of the 210 respondents, $45(21.4 \%)$ rated the utility's performance as 'very good', $52(24.8 \%)$ described it as 'good', $87(41.4 \%)$ felt the performance was 'poor', while $26(12.4 \%)$ said it was 'very poor'. For the convenience of data analysis, 'very good' and 'good' performances were merged into one category designated as 'GOOD', while 'poor' and 'very poor' performances were fused into the category designated as 'POOR'. Based on this, cumulative results show that of the 210 respondents, 94 (44.8\%) rated the utility's performance as GOOD, while $116(55.2 \%)$ described it as 'POOR'. Details are presented under the following sub-sections.

\subsection{Bivariate Analysis of Respondents'Attributes and the Utility's Financial Sustainability}

The study captured information on respondents' background attributes, including Sub Counties of work station, water scheme, job category, gender and highest professional qualification. The attributes were cross-tabulated against the utility's financial sustainability, which was measured in terms of respondents' views regarding the utility's performance in defraying O\&M costs. The results, which are presented in Table 2 show that of the 210 respondents, $84(40.0 \%)$ were stationed in Homa Bay Town Sub County, 62 (29.5\%) worked in Rachuonyo North, 47 (22.4\%) indicated Rachuonyo South, while 17 (8.1\%) were stationed in Mbita Sub County. In relation to the utility's performance in defraying O\&M costs, Table 2 shows that of the 94 respondents who felt that the utility's performance was GOOD, 46 (48.9\%) were stationed in Rachuonyo South, while 23 (24.5\%) worked in Homa Bay Town. Among those who rated performance as POOR (116), 39 (33.6\%) were stationed in Homa Bay Town, while 38 (32.8\%) worked in water schemes located in Rachuonyo South. Based on this, the analysis obtained a computed Chi square $\left(\chi^{2}\right)$ value of 5.753, with 3 degrees of freedom (df) and a $\rho$-value of 0.124 , which suggests lack of a significant association between Sub Counties hosting work stations and views regarding the utility's performance in defraying O\&M costs. The results further suggest that the utility's performance did not vary significantly across the four Sub Counties covered by the study. 
Table 2. Cross-tabulation of respondents' attributes and the utility's performance

\begin{tabular}{|c|c|c|c|c|c|c|c|c|c|}
\hline \multirow{3}{*}{$\begin{array}{l}\text { Respondents' } \\
\text { attributes }\end{array}$} & \multicolumn{6}{|c|}{ Utility's performance in defraying $O \& M$ costs } & \multirow{2}{*}{\multicolumn{3}{|c|}{$\begin{array}{l}\text { Summary of } \\
\text { Square Results }\end{array}$}} \\
\hline & \multicolumn{2}{|c|}{ GOOD } & \multicolumn{2}{|c|}{ POOR } & \multicolumn{2}{|c|}{ TOTAL } & & & \\
\hline & Count & Percent & Count & Percent & Count & Percent & $\chi^{2}$ & $\begin{array}{l}d \\
f\end{array}$ & $\rho$-value \\
\hline \multicolumn{10}{|l|}{$\begin{array}{l}\text { Sub County of work } \\
\text { station }\end{array}$} \\
\hline Homa Bay Town & 23 & 24.5 & 39 & 33.6 & 62 & 29.5 & & & \\
\hline Rachuonyo North & 18 & 19.1 & 29 & 25.0 & 47 & 22.4 & 5.753 & 3 & 0.124 \\
\hline Rachuonyo South & 46 & 48.9 & 38 & 32.8 & 84 & 40.0 & & & \\
\hline Mbita & 7 & 7.4 & 10 & 8.6 & 17 & 8.1 & & & \\
\hline Total & 94 & 100.0 & 116 & 100.0 & 210 & 100.0 & & & \\
\hline \multicolumn{10}{|l|}{ Job category } \\
\hline Managerial & 24 & 25.5 & 5 & 4.3 & 29 & 13.8 & & & \\
\hline Operations & 16 & 17.0 & 13 & 11.2 & 29 & 13.8 & & & \\
\hline Technical & 31 & 33.0 & 54 & 46.6 & 85 & 40.5 & 23.921 & 4 & $0.000 * * *$ \\
\hline Commercial & 16 & 17.0 & 27 & 23.3 & 43 & 20.5 & & & \\
\hline Finance & 7 & 7.4 & 17 & 14.7 & 24 & 11.4 & & & \\
\hline Total & 94 & 100.0 & 116 & 100.0 & 210 & 100.0 & & & \\
\hline \multicolumn{10}{|l|}{ Gender } \\
\hline Male & 76 & 80.9 & 93 & 80.2 & 169 & 80.5 & & & \\
\hline Female & 18 & 19.1 & 23 & 19.8 & 41 & 19.5 & 0.051 & 1 & 0.902 \\
\hline Total & 94 & 100.0 & 116 & 100.0 & 210 & 100.0 & & & \\
\hline \multicolumn{10}{|c|}{$\begin{array}{l}\text { Highest professional } \\
\text { qualification }\end{array}$} \\
\hline Certificate & 47 & 50.0 & 57 & 49.1 & 104 & 49.5 & & & \\
\hline Diploma & 39 & 41.5 & 53 & 45.7 & 92 & 43.8 & 1.885 & 3 & 0.597 \\
\hline Bachelors degree & 7 & 7.4 & 6 & 5.2 & 13 & 6.2 & & & \\
\hline Masters degree & 1 & 1.1 & 0 & 0.0 & 1 & 0.5 & & & \\
\hline Total & 94 & 100.0 & 116 & 100.0 & 210 & 100.0 & & & \\
\hline
\end{tabular}

Regarding job categories, 85 (40.5\%) respondents were in technical positions, 43 (20.5\%) stated job titles that fall under the commercial category, $29(13.8 \%)$ indicated managerial positions, another $29(13.8 \%)$ were in operations, while $24(11.4 \%)$ served in the finance department. Among those who felt that the utility's performance in defraying O\&M costs was GOOD (94), 31 (33.0\%) were in the technical job category, while 24 (25.5\%) held managerial positions. Among the 116 respondents who rated the utility's performance as POOR, 54 (46.6\%) belonged to the technical category, while 27 (23.3\%) indicated titles affiliated to the commercial job category. Based on this, the analysis obtained a computed $\chi^{2}$ of 23.921 , with 4 degrees of freedom and a $\rho$-value of 0.000 , which suggests up to $99 \%$ chance that the utility's performance in defraying O\&M costs significantly associated with respondents' job category. This further suggests that views regarding the utility's performance varied significantly among respondents in the five job categories.

In terms of gender, the respondents included 169 (80.5\%) men and 41 (19.5\%) women. Among those who described the utility's performance as GOOD (94), up to 76 (80.9\%) were men; while among those who felt the performance was POOR (116), men still formed the majority at $93(80.2 \%)$. However, the analysis revealed lack of a significant association between the utility's performance in defraying O\&M costs and respondents' gender $\left(\chi^{2}=0.051, \mathrm{df}=1 \& \rho\right.$-value $\left.=0.902\right)$, which suggests that there was no significant variation in views expressed by male and female respondents regarding the utility's performance.

The results in Table 2 further show that the respondents had attained various levels of professional qualifications, with nearly one-half, 104 (49.5\%), holding certificates and 92 (43.8\%) having diplomas; while 13 (6.2\%) indicated bachelors degree qualifications. Among those who rated the utility's performance as GOOD (94), 47 $(50.0 \%)$ held certificate level qualifications and 39 (41.5\%) stated diplomas; while among those who described performance as POOR (116), 57 (49.1\%) held certificate qualifications and $53(45.7 \%)$ mentioned diplomas. Based on this, the analysis obtained a computed $\chi^{2}$ value of 1.885 , with 3 degrees of freedom and a $\rho$-value of 0.597, which suggests lack of a significant association between the utility's performance in defraying O\&M costs and respondents' highest professional qualifications. This further suggests that views of degree, diploma and certificate holders regarding the utility's performance were fairly homogenous. 


\subsection{Bivariate Analysis of Revenue Generation Aspects and the Utility's Financial Sustainability}

Water sector reforms brought in the aspect of commercialization of water services, which was intended to orient water utilities towards cost recovery, efficiency and financial sustainability. Revenue generation is the principal avenue through which water utilities can surmount financial constraints and achieve financial sustainability. This study examined five aspects of revenue generation, which were identified through a review of policy and empirical literature, including efficiency of the billing system, efficiency of revenue collection, appropriateness of water tariff in relation to cost recovery, non-revenue water, as well as unaccounted for water. The stated aspects were used to formulate hypothetical test statements/items, against which respondents were requested to indicate their honest views on a five-point measurement scale, which was calibrated as 'strongly agree', 'agree', 'undecided', 'disagree' and 'strongly disagree'.

The first hypothetical test item stated that 'the utility's billing system is efficient'. As indicated in Table 3, of the 210 respondents, $141(67.1 \%)$ disagreed with the test statement, while $22(10.5 \%)$ disagreed strongly. On the other side of the scale, $33(15.7 \%)$ respondents agreed with the statement, while $8(3.8 \%)$ agreed strongly. Cumulative results show that $163(77.6 \%)$ respondents expressed disagreement with the statement, which suggests that the utility's billing system was inefficient, according to majority of the respondents. Contrastingly, $41(19.5 \%)$ respondents indicated agreement with the statement. Furthermore, of the 94 respondents who described the utility's performance in defraying O\&M costs as GOOD, 56 (59.6\%) disagreed with the statement, while $22(23.4 \%)$ agreed. Among those who rated the utility's performance as POOR (116), 85 (73.3\%) disagreed with the statement, while 15 (12.9\%) disagreed strongly. Based on the cross-tabulation results, the analysis revealed up to $99 \%$ chance that association between the utility's performance in defraying O\&M costs and efficiency of the utility's billing system was statistically significant $\left(\chi^{2}=27.854, \mathrm{df}=4 \& \rho\right.$-value $=0.000$ ). The results suggest that efficiency of the billing system strongly associated with the utility's potential to achieve financial sustainability, particularly by influencing the amount of revenue generated over a given period of time.

Table 3. Cross-tabulation of revenue generation aspects and financial sustainability of the utility

\begin{tabular}{|c|c|c|c|c|c|c|c|c|c|}
\hline \multirow{3}{*}{$\begin{array}{l}\text { Revenue generation } \\
\text { aspects }\end{array}$} & \multicolumn{6}{|c|}{ Utility's performance in defraying $O \& M$ costs } & \multirow{2}{*}{\multicolumn{3}{|c|}{$\begin{array}{l}\text { Summary of Chi Square } \\
\text { Results }\end{array}$}} \\
\hline & \multicolumn{2}{|c|}{ GOOD } & \multicolumn{2}{|l|}{ POOR } & \multicolumn{2}{|c|}{ TOTAL } & & & \\
\hline & Count & Percent & Count & Percent & Count & Percent & $x^{2}$ & $d f$ & $\rho$-value \\
\hline \multicolumn{10}{|l|}{$\begin{array}{l}\text { Utility's billing system } \\
\text { is efficient }\end{array}$} \\
\hline Agree strongly & 7 & 7.4 & 1 & 0.9 & 8 & 3.8 & & & \\
\hline Agree & 22 & 23.4 & 11 & 9.5 & 33 & 15.7 & & & \\
\hline Undecided & 2 & 2.1 & 4 & 3.4 & 6 & 2.9 & 27.854 & 4 & $0.000 * * *$ \\
\hline Disagree & 56 & 59.6 & 85 & 73.3 & 141 & 67.1 & & & \\
\hline Disagree strongly & 7 & 7.4 & 15 & 12.9 & 22 & 10.5 & & & \\
\hline Total & 94 & 100.0 & 116 & 100.0 & 210 & 100.0 & & & \\
\hline \multicolumn{10}{|l|}{$\begin{array}{l}\text { Revenue collection } \\
\text { has reached sector } \\
\text { benchmark of }>90 \%\end{array}$} \\
\hline Agree strongly & 0 & 0.0 & 0 & 0.0 & 0 & 0.0 & & & \\
\hline Agree & 42 & 44.7 & 11 & 9.5 & 53 & 25.2 & & & \\
\hline Undecided & 4 & 4.3 & 3 & 2.6 & 7 & 3.3 & 15.573 & 4 & $0.004 * * *$ \\
\hline Disagree & 41 & 43.6 & 90 & 77.6 & 131 & 62.4 & & & \\
\hline Disagree strongly & 7 & 7.4 & 12 & 10.3 & 19 & 9.0 & & & \\
\hline Total & 94 & 100.0 & 116 & 100.0 & 210 & 100.0 & & & \\
\hline \multicolumn{10}{|l|}{$\begin{array}{l}\text { Water tariff is optimal } \\
\text { for cost recovery }\end{array}$} \\
\hline Agree strongly & 9 & 9.6 & 6 & 5.2 & 15 & 7.1 & & & \\
\hline Agree & 53 & 56.4 & 44 & 37.9 & 97 & 46.2 & & & \\
\hline Undecided & 3 & 3.2 & 4 & 3.4 & 7 & 3.3 & 9.108 & 4 & $0.058^{*}$ \\
\hline Disagree & 28 & 29.8 & 60 & 51.7 & 88 & 41.9 & & & \\
\hline Disagree strongly & 1 & 1.1 & 2 & 1.7 & 3 & 1.4 & & & \\
\hline Total & 94 & 100.0 & 116 & 100.0 & 210 & 100.0 & & & \\
\hline
\end{tabular}

Non-revenue water is within acceptable 


\begin{tabular}{|c|c|c|c|c|c|c|c|c|c|}
\hline \multicolumn{10}{|l|}{ sector benchmark } \\
\hline Agree strongly & 3 & 3.2 & 1 & 0.9 & 4 & 1.9 & & & \\
\hline Agree & 10 & 10.6 & 29 & 25.0 & 39 & 18.6 & & & \\
\hline Undecided & 1 & 1.1 & 3 & 2.6 & 4 & 1.9 & 36.009 & 3 & $0.000 * * *$ \\
\hline Disagree & 79 & 84.0 & 82 & 70.7 & 161 & 76.7 & & & \\
\hline Disagree strongly & 1 & 1.1 & 1 & 0.9 & 2 & 1.0 & & & \\
\hline Total & 94 & 100.0 & 116 & 100.0 & 210 & 100.0 & & & \\
\hline \multicolumn{10}{|c|}{$\begin{array}{l}\text { Unaccounted for } \\
\text { water is within } \\
\text { acceptable limits }\end{array}$} \\
\hline Agree strongly & 6 & 6.4 & 4 & 3.4 & 10 & 4.8 & & & \\
\hline Agree & 52 & 55.3 & 27 & 23.3 & 79 & 37.6 & & & \\
\hline Undecided & 0 & 0.0 & 2 & 1.7 & 2 & 1.0 & 11.368 & 4 & $0.023 * *$ \\
\hline Disagree & 33 & 35.1 & 70 & 60.3 & 103 & 49.0 & & & \\
\hline Disagree strongly & 3 & 3.2 & 13 & 11.2 & 16 & 7.6 & & & \\
\hline Total & 94 & 100.0 & 116 & 100.0 & 210 & 100.0 & & & \\
\hline
\end{tabular}

The second hypothetical test item stated that 'revenue collection has reached sector benchmark of $>90 \%$ '. In this regard, Table 3 shows that of the 210 respondents, 131 (62.4\%) disagreed with the statement, while 19 (9.0\%) disagreed strongly. On the other side of the scale, $53(25.2 \%)$ respondents agreed with the statement. Cumulatively, the results show that $150(71.4 \%)$ respondents expressed disagreement with the statement, which suggests that revenue collection had not reached the sector's benchmark of more than $90 \%$, at least according to majority of the respondents. Furthermore, among the 94 respondents who rated the utility's performance as GOOD, $42(44.7 \%)$ agreed with the test statement, while $41(43.6 \%)$ disagreed. Contrastingly, of the 116 respondents who felt that the utility's performance was POOR, $90(77.6 \%)$ disagreed with the statement, while $11(9.5 \%)$ expressed agreement. The analysis revealed up to $99 \%$ chance that the utility's performance in defraying O\&M costs significantly associated with the efficiency of revenue collection $\left(\chi^{2}=15.573, \mathrm{df}=4\right.$ \& $\rho$-value $=0.004)$. The results suggest that there was a strong statistical association between efficiency of revenue collection and the utility's potential to achieve financial sustainability.

The third hypothetical test item stated that 'water tariff is optimal for cost recovery'. The results presented in Table 3 show that $97(46.2 \%)$ respondents agreed with the statement, $15(7.1 \%)$ agreed strongly; while 88 (41.9\%) disagreed. Cumulatively, $112(53.3 \%)$ respondents affirmed the statement, which suggests that water tariff was optimal for cost recovery, according to a fair proportion of the respondents. On the other side of the scale, up to $91(43.3 \%)$ respondents expressed disagreement with the statement. In relation to the utility's performance in defraying O\&M costs, the results show that of the 94 respondents who rated the performance as GOOD, 53 (56.4\%) agreed with the statement, while 28 (29.8\%) disagreed. Among those who described the utility's performance as POOR (116), 60 (51.7\%) disagreed with the statement, while 44 (37.9\%) agreed. Based on the cross-tabulation results, the analysis obtained a computed $\chi^{2}$ value of 9.108 , with 4 degrees of freedom and a $\rho$-value of 0.058 , which suggests up to $90 \%$ chance that the utility's performance significantly associated with the appropriateness of water tariff for cost recovery. The results further suggest that the statistical association between water tariff and the utility's potential to achieve financial sustainability was fairly weak.

The fourth hypothetical test item stated that 'non-revenue water is within acceptable sector benchmark'. In this regard, the results presented in Table 3 show that of the 210 respondents, 161 (76.7\%) disagreed with the statement, while 39 (18.6\%) agreed. Cumulatively, 165 (78.6\%) respondents expressed disagreement with the statement, which suggest that non-revenue water was not within acceptable sector benchmark, according to majority of the respondents. Contrastingly, about one-fifth of the respondents, 41 (19.5\%), affirmed the statement. In relation to the utility's performance in defraying O\&M costs, of the 94 respondents who said the utility's performance was GOOD, $79(84.0 \%)$ disagreed with the statement, while $10(10.6 \%)$ indicated agreement. Among those who described the utility's performance as POOR (116), 82 (70.7\%) disagreed with the statement, while $29(25.0 \%)$ agreed. Based on this, the analysis revealed up to $99 \%$ chance that the utility's performance in defraying O\&M costs significantly associated with non-revenue water $\left(\chi^{2}=36.009, \mathrm{df}=3 \&\right.$ $\rho$-value $=0.000$ ). The results suggest a strong statistical association between non-revenue water and the utility's potential to achieve financial sustainability.

Respondents were further requested to indicate their views regarding the fifth hypothetical test item, which 
stated that 'unaccounted for water is within acceptable limits'. The results in Table 3 show that of the 210 respondents, $103(49.0 \%)$ disagreed with the statement, while 16 (7.6\%) disagreed strongly. However, 79 (37.6\%) respondents agreed with the statement, while $10(4.8 \%)$ agreed strongly. Cumulatively, the results show that 119 (56.7\%) respondents expressed disagreement with the statement, which suggests that unaccounted for water was not within acceptable limits, according to more than one-half of the respondents; while on the other side of the scale, $89(42.4 \%)$ affirmed the statement. In relation to the utility's performance in defraying O\&M costs, the results in Table 3 further show that of the 94 respondents who rated the utility's performance as GOOD, 52 (55.3\%) agreed with statement, while $33(35.1 \%)$ disagreed. Among the 116 respondents who described the utility's performance as POOR, 70 (60.3\%) expressed disagreement with the statement, while $27(23.3 \%)$ indicated agreement. Based on this, the analysis obtained a computed $\chi^{2}$ value of 11.368 , with 4 degrees of freedom and a $\rho$-value of 0.023 , which suggests up to $95 \%$ chance that the utility's performance in defraying O\&M costs significantly associated with unaccounted for water. The results suggest a moderate statistical association between unaccounted for water and the utility's potential to achieve financial sustainability.

\subsection{Relative Importance of Revenue Generation Aspects and the Utility's Financial Sustainability}

Bivariate analysis performed in the foregoing sub-section revealed that the utility's potential to achieve financial sustainability significantly associated with all the five revenue generation aspects examined by the study, including efficiency of the billing system, which for the purpose of further analysis using the Relative Importance Index (RII) technique, was coded as $B l_{\text {System }}$. Other aspects included efficiency of revenue collection $\left(R v_{\text {Collections }}\right)$, appropriateness of water tariff in relation to cost recovery $\left(\operatorname{Tr}_{\text {Optimal }}\right)$, non-revenue water $\left(N r_{\text {Water }}\right)$, as well as unaccounted for water $\left(U c_{\text {Water }}\right)$. Table 4 presents the results of RII analysis, which include an inter-item correlation matrix, correlation co-efficients $(\beta)$, general dominance weights and relative weights. The latter indicates the importance of each aspect of revenue generation in relation to the degree of variation in the utility's performance in defraying O\&M costs.

Table 4. Relative importance of revenue generation aspects and the utility's performance

\begin{tabular}{|c|c|c|c|c|c|c|c|c|}
\hline \multicolumn{6}{|c|}{ INTER-ITEM CORRELATION MATRIX } & \multicolumn{3}{|c|}{ RELATIVE IMPORTANCE } \\
\hline $\begin{array}{l}\text { Revenue } \\
\text { generation } \\
\text { aspects }\end{array}$ & $B l_{\text {System }}$ & $R v_{\text {Collections }}$ & $\operatorname{Tr}_{\text {Optimal }}$ & $N r_{\text {Water }}$ & $U c_{\text {Water }}$ & $\beta$ & $\begin{array}{l}\text { General } \\
\text { dominance } \\
\text { weights }\end{array}$ & $\begin{array}{l}\text { Relative } \\
\text { weights }\end{array}$ \\
\hline$B l_{\text {System }}$ & 1.000 & 0.594 & 0.411 & 0.738 & 0.625 & 0.649 & 0.882 & 0.866 \\
\hline$R v_{\text {Collections }}$ & 0.594 & 1.000 & 0.568 & 0.447 & 0.620 & 0.635 & 0.875 & 0.853 \\
\hline$T r_{\text {Optimal }}$ & 0.411 & 0.568 & 1.000 & 0.369 & 0.501 & 0.509 & 0.789 & 0.767 \\
\hline$N r_{\text {Water }}$ & 0.738 & 0.447 & 0.369 & 1.000 & 0.645 & 0.677 & 0.891 & 0.879 \\
\hline$U c_{\text {Water }}$ & 0.625 & 0.620 & 0.501 & 0.645 & 1.000 & 0.527 & 0.807 & 0.790 \\
\hline
\end{tabular}

The results presented in Table 4 show that non-revenue water $\left(N r_{\text {Water }}\right)$ emerged as the most important aspect influencing the largest variation in the utility's performance, with a relative weight of 0.879 . This relates to the bivariate results presented in the previous sub-section, which show that up to $165(78.6 \%)$ respondents hinted that non-revenue water was not within the acceptable sector benchmark. In this regard, key informants estimated that non-revenue water averaged at $35 \%$, which notably was higher than the acceptable average of $20 \%$. The informants affirmed that the utility experienced a high level of non-revenue primarily due to losses in the distribution systems through leakages, faulty water meters, inaccurate meter readings, and inefficient billing system. Respondents noted that due to the high level of non-revenue water, meeting revenue targets was a big challenge for the utility. In this regard, the utility lost about $40 \%$ of its annual revenue targets, which significantly undermined its potential to achieve financial sustainability. Respondents described the resulting imbalance between revenues and financial obligations, as a perennial challenge that precipitated financial constraints, and affected maintenance of the distribution system.

The results in Table 4 further show that efficiency of the billing system $\left(B l_{\text {System }}\right)$ was second in the order of relative importance; based on the degree of variation in the utility's performance in defraying O\&M costs (relative weight $=0.866$ ). This reflects bivariate results presented in the previous sub-section, which show that of the 210 respondents, up to $163(77.6 \%)$ hinted that the utility's billing system was inefficient. In this regard, key informants indicated that the billing process, which was predominantly manual, was constrained by challenges such as delayed uptake of meter readings, delayed compilation of meter data, erroneous computation of bills, 
which manifested through under-costing, and in a few instances, over-costing of water services; as well as delayed distribution of water bills due to logistical challenges. Respondents further noted that under-costing of water services directly reduced revenues, while over-costing triggered complaints among customers, which in turn, led to refusal to pay, disconnections and bad debts. Respondents further noted that some consumers were never billed, due to collusion with water officers, as well as interference by a few influential civil servants and political leaders. Non-payment was particularly a critical challenge with government institutions, whose disconnection from the supply system was constrained by tedious bureaucratic procedures. Even though the utility was in the process of computerizing its billing system, informants noted that the process was painstakingly slow and was constrained by inadequacy of appropriate ICT facilities and technical skills among billing officers.

Efficiency of revenue collection $\left(R v_{\text {Collections }}\right)$ was third in the order of relative importance, with a relative weight of 0.853 . These results concur with bivariate results in the previous sub-section, which show that up to 150 (71.4\%) respondents indicated that collected revenue had not reached the sector's benchmark of more than $90 \%$. Key informants and FGD respondents observed that revenue collection efficiency was largely determined by payments methods adopted by the utility. In this regard, three methods of payment including bank, mobile phone transfer and cash, were cited. Of these, payment through banks was identified as the most dominant method, albeit with issues such as long distance to bank facilities and long queuing time, especially around end month. The challenges resulted to delayed payments, high default rates and disconnections. Respondents further indicated that payment through mobile phone was an upcoming initiative, which was intended to address the challenges inherent in payment through banks. In this regard, respondents noted that the method was gradually picking up and improving revenue collection efficiency, particularly due to its flexibility and convenience, as consumers were able to pay bills from the comfort of their homes. Nonetheless, its impact was yet to be felt as far as default rates, delayed payments and disconnections are concerned.

The results in Table 4 further show that unaccounted for water $\left(U c_{\text {Water }}\right)$ was fourth in the order of relative importance (relative weight $=0.790$ ). Again this concurs with bivariate results presented in the previous sub-section, which indicate that up to $119(56.7 \%)$ respondents felt that unaccounted for water was not within acceptable limits of $20 \%$. Key informants estimated the level of unaccounted for water to be in the range of 30 to $35 \%$, and attributed it to illegal connections and physical leakage from the distribution system before reaching metered consumers. The high level of unaccounted for water was primarily attributed to inadequacy of resources for regular monitoring of the distribution network to facilitate timely detection of leakages and pilferage. Resource constraint also delayed the launch of preventive, corrective and rehabilitative maintenances. These challenges affected the amount of revenue generated, which in turn, undermined the utility's potential to achieve financial sustainability.

The appropriateness of water tariff in relation to cost recovery $\left(T r_{\text {Optimal }}\right)$, emerged fifth in the order of relative importance (relative weight $=0.767$ ). Again this is congruent to bivariate results in the previous sub-section, which indicate that slightly more than one-half of the respondents, $112(53.3 \%)$, affirmed that water tariff was optimal for cost recovery. However, a significant proportion, 91 (43.3\%), felt that water tariff was not optimal for cost recovery. Among key informants and FGD respondents, the analysis revealed three different perspectives regarding the appropriateness of water tariff for cost recovery. Proponents of the first perspective asserted that the level of water tariff had nothing to do with the utility's financial constraints. Instead, they pointed fingers at the billing system, revenue collection, non-revenue water and unaccounted for water, among other aspects, as key factors that contributed to the utility's financial constraints. Proponents of the second perspective indicated that the level of water tariff contributed to the utility's financial constraints by primarily being sub-optimal for cost recovery; while proponents of the third perspective argued that it was difficult to tell whether water tariff was optimal or sub-optimal for cost recovery due to lack of accurate data on the actual cost of producing and delivering water services, as well as maintaining distribution systems.

\subsection{Concordance of Views on Revenue Generation Aspects and the Utility's Financial Sustainability}

The results presented in the foregoing sub-section shows the relative importance of revenue generation aspects, based on the degree of variation in the utility's performance in defraying O\&M costs. The analysis relied on respondents' subjective views, whose validity depends on the extent to which such views expressed by different respondents concur or converge. In this sub-section, the analysis focused on determining the extent to which respondents' views regarding the relative importance of revenue generation aspects vis-à-vis the utility's financial sustainability converged. In this regard, Table 5 shows that the analysis yielded mean ranks for each aspect of revenue generation, Kendall's Coefficient of Concordance (W) and Chi square $\left(\chi^{2}\right)$ statistic with related $\rho$-value, which indicates statistical significance of convergence among views expressed by different respondents. In this regard, the results in Table 5 show that the level of non-revenue water $\left(N r_{\text {Water }}\right)$ with a mean rank of 3.826 , 
emerged first based on its strength of association with the utility's financial sustainability. Ranking second was efficiency of the billing system $\left(B l_{\text {System }}\right)$ with a mean rank of 3.633 , followed by efficiency of revenue collection $\left(R v_{\text {Collections }}\right)$, level of unaccounted for water $\left(U c_{\text {Water }}\right)$ and appropriateness of water tariff in relation to cost recovery $\left(\operatorname{Tr}_{\text {Optimal }}\right)$.

Table 5. Concordance of views regarding revenue generation aspects

\begin{tabular}{|c|c|c|c|}
\hline \multicolumn{2}{|l|}{ Ranks } & \multicolumn{2}{|l|}{ Test Statistics } \\
\hline Revenue generation aspects & Mean Rank & $\mathrm{N}$ & 210 \\
\hline BlSystem & 3.633 & Kendall's W ${ }^{\mathrm{a}}$ & 0.893 \\
\hline RvCollections & 3.481 & Chi-Square $\left(\chi^{2}\right)$ & 71.222 \\
\hline TrOptimal & 3.019 & df & 4 \\
\hline NrWater & 3.826 & $\rho$-value & 0.000 \\
\hline UcWater & 3.187 & $\begin{array}{l}\text { a. Kendall's } \\
\text { Concordance }\end{array}$ & icient of \\
\hline
\end{tabular}

The analysis obtained a Coefficient of Concordance (Kendall's W) of 0.893, which suggests a strong level of convergence of the views expressed by different respondents regarding the relative importance of revenue generation aspects vis-à-vis the utility's financial sustainability. The analysis also obtained a computed $\chi 2$ of 71.222 , with 4 degrees of freedom (df) and a $\rho$-value of 0.000 , which suggest up to $99 \%$ chance that respondents' views were concordant. The results suggest that all the respondents concurred that revenue generation aspects examined by the study significantly influenced the utility's potential to achieve financial sustainability.

\section{Summary, Conclusion and Implications}

The study set to determine revenue generation aspects that influence HOMAWASCO's financial sustainability, with a view to demonstrating how well the utility prepared its revenue generation operations in order to achieve financial sustainability in the commercialized water market. The results show that non-revenue water (NrWater) was the most important aspect of revenue generation that influenced the largest variation in the utility's performance in defraying O\&M costs, with a relative weight of 0.879 . This was followed by efficiency of the billing system $($ BlSystem) (relative weight $=0.866$ ); efficiency of revenue collection (RvCollections), with a relative weight of 0.853; unaccounted for water (UcWater) (relative weight $=0.790$ ); as well as appropriateness of water tariff in relation to cost recovery (TrOptimal), which generated a relative weight of 0.767 . The analysis also obtained a strong and significant concordance of views expressed by different respondents regarding the relative importance of revenue generation aspects vis-à-vis the utility's financial sustainability (Kendall's W= $0.893, \chi 2=71.222, \mathrm{df}=4 \& \rho$-value $=0.000$ ); implying that all the respondents concurred that revenue generation aspects examined by the study significantly influenced the utility's potential to achieve financial sustainability. The results further imply that the revenue generation pillar was not adequately set to enable the utility achieve financial sustainability in the commercialized water market.

Water sector reforms, through commercialization of services, precipitated the need for all WSPs to enhance internal capacity for successful functioning in a competitive water market. The Four Pillars Model of Financial Sustainability identifies key components that WSPs need to enhance in order to set themselves on the right path to financial sustainability, including income/revenue generation. However, the results of this study create an impression that the utility's revenue generation pillar was inadequately prepared for financial sustainability, as indicated by most respondents. High proportions of non-revenue and unaccounted for water signals loss of revenue. However, reducing non-revenue and unaccounted for water is a daunting challenge, particularly in contexts where public water utilities lack appropriate technology and technical skills for early detection of leakages, pilferage, defective meters, as well as budgetary resources for timely launch of preventive, corrective and rehabilitative maintenance. In Kenya, the water sector is constrained by perennial budgetary deficits, which makes it difficult for the public water utilities to acquire necessary technology and expertise for addressing non-revenue and unaccounted for water. Consequently, there is no doubt that the twin challenges will continue militating against the utility's potential to achieve financial sustainability. Nonetheless, the utility's board and management should focus on continuous engagement with development partners, with a view to mobilizing 
supplementary resources for necessary equipment, and technical support. Equally important is the need for active partnership with community administrative structures and groups for early detection and reporting of physical leakages, spillage, illegal connections and defective metering equipment.

Efficiency of billing systems is primarily, a function of the type of systems adopted by water utilities, alongside operational efficiency and administrative effectiveness. Whereas manual systems are prone to inaccuracy and inefficiency, computerized systems are likely to generate more accurate bills at less cost and time. Regardless of the type of billing systems adopted by a utility, the accuracy of bills and efficiency of the billing process are crucial antecedents for achieving revenue targets. Consequently, transition from manual billing systems to computerized systems is an inevitable necessity for public water utilities to function in a commercialized water market. Notably though, the transition process is a capital-intensive undertaking, which requires appropriate ICT hardware facilities and software programs, as well as technical support in building workers' capacity. Even though the utility had initiated computerization of the billing system, the process was yet to be completed. This study amplifies the need for water authorities and the county governments to prioritize upgrading of billing systems through their investment plans.

Efficient revenue collection systems employ payment methods that motivate customers to pay their bills early by reducing costs of forgone opportunities, accessing payment points and effecting transactions. Early payment of water bills is crucial for public utilities to obtain revenues for defraying O\&M costs. It also prevents disconnections and bad debts, which deny water utilities revenues. In view of this, any attempt to enhance financial sustainability of public water utilities should not overlook the need to improve payment methods, particularly in terms of versatility, convenience and cost implications. In Kenya, the advent of mobile phone payment methods provides an important option, which enables consumers to overcome challenges inherent in payment through banks and cash. Promoting the mobile phone payment method is an option that the utility should consider in order to improve revenues and achieve financial sustainability.

Appropriateness of water tariff for cost recovery is also crucial for public water utilities to improve revenues and achieve financial sustainability. An optimal water tariff enables utilities to generate sufficient revenue for O\&M costs, while incentivizing customers to pay for services rendered. Notably though, setting water tariff is a critical process which should ensure that low revenue-earners are not over-charged and water utilities are not under-paid for their services. The challenge is greater in developing countries, where most domestic consumers live below the poverty line and access to water services often used by some leaders to advance political interests. Even though optimal tariff is an indispensable antecedent for public water utilities to achieve financial sustainability, setting an optimal water tariff requires accurate and complete data on production, distribution and maintenance costs, which however, were lacking in the utility covered by the study. Thus, initiating appropriate monitoring and data capture systems is a crucial intervention, which should be prioritized by stakeholders to enable the utility set and manage optimal water tariffs from time to time, in order to improve revenues.

\section{References}

Abebe, T., Bosona, T., \& Gebresenbet, G. (2013). Rural Water Supply Management and Sustainability: The Case of Adama Area, Ethiopia. Journal of Water Resource and Protection, 5(1), 208-221.

Adams, A. (2012). Financial Sustainability of Rural Water Supplies in Western Kenya: Comparing Technology Types and Management Models. A Thesis Submitted for the Award of Master of Science in Civil Engineering Degree at the Department of Water Management, Delft University of Technology, Netherlands.

Adank, M., \& Tuffuor, B. (2013). Management Models for the Provision of Small Town and Peri-Urban Water Services in Ghana: TPP Synthesis Report. Accra. TPP Project/RCN Ghana.

Ashley, D., \& Orenstein, D. M. (2005). Sociological Theory: Classical Statements (6 ${ }^{\text {th }}$ Ed.). Boston, MA, USA: Pearson Education.

Banerjee, S. G., \& Morella, E. (2011). Africa's Water and Sanitation Infrastructure: Access, Affordability, and Alternatives. Washington DC: World Bank.

Bowman, W. (2011). Financial Capacity and Sustainability of Ordinary Non-profits. Non-profit Management and Leadership, 22(1), 37-51. https://doi.org/10.1002/nml.20039

Castro, V., Msuya, N., \& Makoye, C. (2009). Sustainable Community Management of Urban Water and Sanitation Schemes: A Training Manual. Nairobi: WASP.

Check, K. (2015). An Impact Study of Two Models of Community-Based Water Management in Uganda. Practicing Anthropology, 37(2), 12-16. https://doi.org/10.17730/praa.37.2.r11m5370t1v57520 
Easterby-Smith, M., Thorpe, R., \& Lowe, A. (1991). The Philosophy of Research Design. Management Research: An Introduction. London: Sage Publications.

Fink, A. (1995). The Survey Kit: How to Sample in Surveys. Thousand Oaks, CA: Sage Publications.

Fragano, F. (2010). Management Models for Peri-Urban Community Water Projects in Paraguay. Itagua: Community Water Board.

Frauendorfer, R. \& Liemberger, R. (2010). The Issues and Challenges of Reducing Non-Revenue Water. Mandaluyong City: Asian Development Bank.

Garson, G. D. (2009). Reliability Analysis. Journal of Modern Applied Statistical Methods, 6(1), 21-29.

Gia, L. H. \& Fugelsnes, T. (2010). Public Partnerships for Small Piped Water Schemes. Nairobi: Water and Sanitation Program.

Government of Kenya. (2002). Water Act No. 8 of 2002. Nairobi: Government Printer.

Hughes, J. A., \& Sharrock, W. W. (1997). Philosophy of Social Research (3rd ed.). London: Longman

K'Akumu, O. A., \& Appida, P. O. (2006). Privatization of urban water service provision: the Kenyan experiment. Water Policy, 8(4), 313-324. https://doi.org/10.2166/wp.2006.044

K'Akumu, O. A. (2006). Privatization Model for Water Enterprise in Kenya. Water Policy, 8(1), 539-557. https://doi.org/10.2166/wp.2006.047

Kibuika F. M., \& Wanyoike, D. (2012). Assessment of Factors Affecting Sustainability of Rural Water Supply Schemes in Nyandarua County, Kenya: A Case of Kangui Water Scheme. International Journal of Science and Research, 3(8), 578-584.

León, P. (2001). Four Pillars of Financial Sustainability. Arlington, Virginia: The Nature Conservancy.

McPhail, A., Locussol, A. R., \& Perry, C. (2012). Achieving Financial Sustainability and Recovering Costs in Bank Financed Water Supply and Sanitation and Irrigation Projects. Washington, D.C.: The World Bank.

Mimrose, D. M., Gunawardena, E. R. N., \& Nayakakorala, H. B. (2011). Assessment of Sustainability of Community Water Supply Projects in Kandy District. Tropical Agricultural Research, 23(1), 51- 60. https://doi.org/10.4038/tar.v23i1.4631

Norman, G., \& Parker, W. (2011). Business Model for Delegated Management of Local Water Services Experience from Naivasha Kenya. Nairobi: WSUP.

Obosi, J. O. (2011). Public Private Partnerships in the Privatization of Water Service Delivery in Kenya: Current Issues of Water Management, Available from http://www.intechopen.com/books

Polit, D. E. \& Beck, C. T. (2006). Essentials of Nursing Research, (6th ed.). Philadelphia: Lippincott Williams \& Wilkins.

Poverty-Environment Partnership (PEP). (2006). Linking Poverty Reduction and Water Management. New York: United Nations Development Programme.

Rampa, F. (2011). Analyzing Governance in the Water Sector in Kenya. Discussion Paper No. 124. Nairobi.

Sale, J. E. M., Lohfeld, L. H., \& Brazil, K. (2002). Revisiting the Quantitative-Qualitative Debate: Implications for Mixed Methods Research. Quality and Quantity, 36(1), 43-53. https://doi.org/10.1023/A:1014301607592

Sanders, H., \& Fitts, J. (2011). Assessing the Sustainability of Rural Water Supply Programs: A Case Study of Pawaga, Tanzania. A Thesis submitted for the Award of Master of Arts Degree at Duke University.

Sheatsley, P. B. (1983). Questionnaire Construction and Item Writing. In Rossi, P. H., Wright, J. D., \& Anderson, A. B. (Eds.), Handbook of Survey Research. San Diego, CA: Academic Press, Inc. https://doi.org/10.1016/B978-0-12-598226-9.50012-4

United Nations Children's Fund (UNICEF), \& World Health Organization (WHO) (2015). Joint Monitoring Program Report. New York: WHO.

United Nations Development Programme (UNDP). (2010). GOAL WaSH Programme: Country Sector Assessments Volume 2. Governance, Advocacy and Leadership for Water, Sanitation and Hygiene. New York: UNDP.

Wambua, S. (2004). Water Privatization in Kenya: Global Issue Papers, No.8. Berlin: Heinrich Foundation. 
Water Resources Management Authority (WRMA). (2013). Impact: A Performance Report of Kenya's Water Sector Reforms. Nairobi: WASRB.

Whittington, D., Davis, J., Prokopy, L., Komives, K., Thorsten, R., Lukacs, H., ... Wakeman, W. (2009). How Well Is the Demand - driven, Community Management Model for Rural Water Supply Systems Doing? Evidence from Bolivia, Peru and Ghana. Water Policy, 11, 696-718. https://doi.org/10.2166/wp.2009.310

Williams, K. S. (2013). Non-Profit Financial Sustainability. A Thesis Submitted in Partial Fulfillment of the Requirements for the Degree of Master of Arts in Interdisciplinary Studies, Dalhousie University.

Wong, P. W. (2014). A Snapshot on Qualitative Research Methods. Educational Research and Reviews, 9(5), 130-140. https://doi.org/10.5897/ERR2014.1801

World Bank. (2006). The Challenge of Reducing Non-Revenue Water in Developing Countries. Washington, DC: World Bank.

World Bank. (2008). Water Sector Reforms: Five Years On. New York: Water and Sanitation Program-Africa/World Bank.

World Bank. (2012). Public Partnerships for Rural Water Services. Briefing Note No. 4. Washington, DC: World Bank.

\section{Copyrights}

Copyright for this article is retained by the author(s), with first publication rights granted to the journal.

This is an open-access article distributed under the terms and conditions of the Creative Commons Attribution license (http://creativecommons.org/licenses/by/4.0/). 